\title{
A case from school psychology (bullying victimization)
}

Volume 9 Issue I - 2018

\section{Introduction}

M.A 12 years old boy studied in class $7^{\text {th }}$. He was referred by the teacher for the management of his academic problems. Complaints which were reported by his teacher were weak in studies, problem in reading and writing and didn't speak in class. During the session in clinical interview client report certain presenting complaints like being fearful while giving oral test in class or while reading in class, difficulty in memorizing science lesson, difficulty in reading and writing difficult words of Urdu and English, some class fellows make fun of him. Different assessment modalities like behavioral observation, Clinical Interview, Subjective rating scale, Baseline charts, Emotional behavioral assessment (School children problem scale), Academic assessment (reading, coping, Dictation), Cognitive assessment (paired associate learning test, Urdu reading, digit span test, logical memory test) and reinforce identification were done with the child in order to assess his problem.

The assessment results reveal that he was victim of bullying. certain counseling strategies were used with the client like rapport building, prioritizing goals, daily activity scheduling and psycho-education , Assertiveness training (broken record technique) Chunking (making outline of a paragraph), Cost and benefit analysis, study skills, changing old rules assumptions into new rules assumptions, Situation exposure hierarchy technique and for phonetic awareness flipbook and words family chart. Till now 10 sessions had been done with the client. And overall client's behavior was cooperative in every activity. Outcome of the therapeutic intervention was fruitful as he learned assertiveness and he was also not afraid of telling his authoritative figure about any bully issues at school. Client had phonetic awareness as well.

\section{Identifying data}

\begin{tabular}{ll}
\hline Name: M.A & Age: I2 \\
Gender: Boy & Class: $7^{\text {th }}$ \\
School: M.H.S & Informant:Teacher \\
No of sessions: 12 & Date seen: $7-4-2015$ \\
Last date seen: $26-5-2015$ & \\
\hline
\end{tabular}

\section{Reason for referral}

The child was referred by the teacher for the purpose of assessment and management of his current academic problems.

\section{Presenting complaints}

Presenting complaints and duration of the client's problems according to the client

a. Being fearful while giving oral test in class or while reading in class

b. Difficulty in memorizing science lesson

\author{
Maaza Chaudhary \\ Clinical Psychologist at Special Kids Inn, Pakistan
}

Correspondence: Maaza Chaudhary, Clinical Psychologist at Special Kids Inn, Pakistan, Email maaza.aeed@yahoo.com

Received: August 16, 2015 | Published: January 09, 2018 c. Difficulty in reading and writing difficult words of Urdu and English

d. Some class fellows make fun of him

e. Presenting complaints and duration of the client's problems according to the teacher of the client

f. Weak in studies

g. Problem in reading and writing

h. Didn't speak in class

\section{Initial observation}

Client M.T belonged to a lower socio economic class and separate family system his birth order was $4^{\text {th }}$ and he was 12 years old boy studied in class $7^{\text {th }}$. When M.A entered in the session room he was holding his note books and his head and back was bend. His facial expressions were fearful and he was grinding his pencil by putting it in mouth. He was sitting at the left side of the chair with twitching legs. His hygiene condition is not appropriate as he wore tainted dress. He didn't maintain and take initiative in eye contact. His voice tone was not audible. Still after defining the therapist role and insured him about confidentiality client was seems anxious in the whole session.

\section{Developmental history of the problem}

Problem of the M.A was started 5years earlier when he was moved from private school to the current Government school. But problem of the client trigger again in last 2years. Earlier he studied in a private school where his performance was 70 percent and his favorite subjects there were Urdu and Islamite and his favorite teacher was Urdu subject teacher.

But he moved to Gov School 5years back in 2011 because his parent's didn't bear the expenses of private school. His performance 
was average till $5^{\text {th }}$ class but in previous two years his academic performance decline rapidly as he faced difficulty in memorizing science lesson and remembering and reading Urdu and English words. Addition of some new class fellows in client's class from previous two years was a big change for him as they make fun of the client and call him with different names and even sometimes take his money and force him to do certain tasks like go out of class and bring something for him.

At home from last some months he often do demands with his parent's like buying a new bicycle or clothes but parent's sometimes couldn't meet his expectations and he started showing tantrums like crying for whole day, stops taking daily food and refuses to go to school or tuition for studies.

Client reported that he had difficulty in reading and writing English and Urdu words and he tried to memorize science lesson but he couldn't memorize even a single passage. He had joined tuition for extra help but still he didn't sort out his academic problem. He thought that his class fellow's know more than him. It was reported by the child whenever there is any test or paper and he studied at home his mother or someone from his neighborhood ask him to bring something from bazaar and after that activity he lose his attention in studies. Parents of the client demand about good grades but when client hardly gets passing marks father of the client beat and scold him and often mother of the client also beat and scold him on his demanding behavior.

\section{Background information}

\section{Personal history}

Client M.A had a schedule daily routine the daily routine of the child was, he woke up at 7.00 for school and starting preparation for school. He goes to school at 8:00 am and came back from school near 2:15 pm then at 3:00 he go to academy and came back at 6:00pm. Before going to mosque for Qur'an education at 7.00 he take his dinner. At 8:00 clock he came back from mosque and watching T.V after that he done his homework and then go to sleep.

He likes watching different cartoons on TV. He also likes playing cricket. He didn't like watching daily serials at T.V. During his free time he likes to watch cartoon and play cricket with his elder brother. He had only one best friend in school.

\section{Family history}

Client M.T belonged to a lower socio economic background and separate family system. Total number of client's family members was seven. His father had a chips corner on a footpath. Father of the client was most of the time behave peevishly with everyone at home. Client had distant relationship with his father because of the strict attitude of the father. Father of the client beat and scold him when he hardly gets passing marks in exams. Mother of the client was a lady tailor and done his work at home. Most of the time she pressurize the client on achieving good grades. Mother of the client often beat him because of client's demanding behavior. Parent's relationship with each other is not very much affectionate as they quarreled with each other on their economic conditions. Client had 4 siblings. First born was sister and she was studying in a Government college. Her relationship with the client was loving and caring as she used to bring candies for him. And client also do house hold related works for his sister like bringing something from bazaar for her etc.

$2^{\text {nd }}$ born was brother and he was working in an auto mobile work shop. When he came back from his workshop he often play cricket with the client. But most of the time he scold the client when client refused to bring something from bazaar or anything from kitchen.

$3^{\text {rd }}$ born was sister and she's studying in a Government school. Client and she often had fight with each other. She had very strict schedule and she often had interaction with the client mostly on weekends.

$4^{\text {th }}$ born was client. And $5^{\text {th }}$ born was a brother. He's 8 years old and client and he didn't share any strong bond with each other although they play cricket every day after school but after every game they had fight and because of it client was beaten up by his mother and mother of the client scold him, that he should be careful while playing with his brother as his brother was younger than him. And because of it client often thought that mother of the client is more affectionate with his younger brother and his younger brother is the favorite child of his mother.

Overall family environment was disturbed as family members often had conflicts with each other's on household related issues and because of the father's strict attitude.

Family genogram: The family genogram shows the strength of every relation.

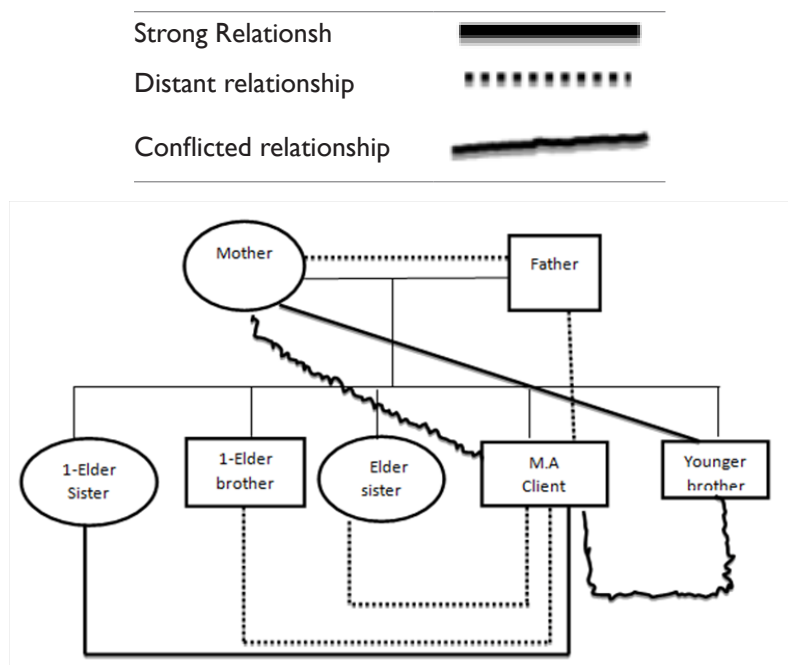

Educational History: Client's schooling started at the age of 4years he was admitted in a private school he studied there till $4^{\text {th }}$ grade. His performance there was average as he got 70 percent marks there. His favorite teacher was Urdu and Islamite subject teachers.

After $4^{\text {th }}$ grade client was admitted in a Government school initially his performance was average but later on when his new class fellows came and they started make fun of him, calling his different names and force him to bring things from outside of the class when teacher was about to came in the class. And client didn't report about them to any one in his home and in his school.

when client had any test or assigned task in tuition or in school and he starting memorizing lesson, someone from his neighborhood or from his home ask him to bringing stuff from bazaar after that client lose interest in studies and then face difficulty in his academic performance by getting less marks. Currently client had problem in memorizing science lesson. He also faces difficulty in remembering and writing English and Urdu words. He had difficulty while reading in class and when teacher take oral test or ask him to read something he starting shivering. And he thinks his other class fellow's knows more than him. Client likes his Urdu teacher because he's very kind 
it was reported by the client in a session. Client had only one best friend at school. He wants to join army after completing his studies. He wanted to overcome his academic problem it was reported by the client.

\section{Provisional formulation}

According to the bio psycho social model M.T was not predisposed to have this problem and he was physically and mentally healthy as well. Psychological factors of client's problem were his thought pattern that others know more than him in studies, his mother loves his younger brother more than him, loss of interest in studies after bringing something from bazaar for someone. The social factors of the client's problem were his parental pressure on getting good marks, less number of friends, bullying at school and strict attitude of parent's.

Risk factors of client's problem were parental pressure, interruption in studying because of which loss of interest in studies, his view mother is more affectionate towards his younger brother, his view others know more than him in studies and conflicted home environment. Protective factors were loving relationship with elder sister, his best friend and client's own attitude toward overcoming his academic problem. Maintaining factors of client's problem were parental pressure regarding getting good marks, bullying at school, client's view regarding mother's affectionate relation towards his younger brother, father's peevish attitude, and interruption of family member or from neighborhood for bringing stuff from bazaar while he's busy in his studies.

\section{History of psychiatric and medical illness}

No history of psychiatric or any medical illness was reported by the child yet.

\section{Assessment}

Different assessment modalities were used with the client in order to assess the problem of the client.
i. Behavioral Observation
ii. Clinical Interview
iii. Behavioral Checklist
iv. Subjective Rating Scale
v. Baseline Charts
vi. Emotional behavioral Assessment
vii. Academic Assessment
viii. Cognitive Assessment
ix. Reinforce identification

\section{Behavioral observation}

Behavioral observation was done during the session to know about the behavior and personality of the client. Participant observation was couldn't be done as participation of the therapist in the class or in the playground was not allowed in the school because of the limitation of the school authority.

\section{Observation during the session}

Client was observed during sessions, in which his appearance, hygiene condition, behavior was observed. Further his mood, communication and interaction with the therapist was also observed. Client's sitting posture and voice volume was observed. And it was observe that he was anxious in the initial session, his hygiene was not appropriate. He was sitting in bending position at the extreme left side of the chair. His speech was clear but voice tone was not audible.

\section{Clinical interview}

Clinical interview was done with the client in order to take the indepth history of the problem of the client.

Clinical interview with the client: Clinical interview was done with the client in order to know about the problem of the client according to the client's view. Client was aware of his problem and wants to get rid of his academic problem. Client was asked about different questions in clinical interview like how his problem was started, his favorite subject, favorite teacher, his home environment, daily routine, his hobbies and his likes and dislikes.

Clinical interview with the teacher of the client: Clinical interview was done with the teacher of the client in order to know about the problem of the client according to his teachers view. Teacher was asked about history of the problem of the client and client's behavior and performance in the class.

\section{Subjective rating scale ${ }^{1}$}

Subjective rating scale was also used in the assessment for the purpose of knowing the client's insight regarding his severity of the problem. He was ask to rate his problem out of 10 (Table 1). Subjective rating was taken from the client in order to know about the severity of the problem of the client and client rate his problem out of 10 . He rate his problem of being fearful while giving oral test in class or while reading in class 10 out of 10 which shows the anxiety level of the client and his awareness regarding his problem as well. Client rate his problem of difficulty in memorizing science lesson 9 out of 10 which shows that he knew about his weakness in particular subject. He rate his problem of difficulty in reading and writing difficult words of Urdu and English 10 out of 10 which shows that he had awareness regarding his weak points in studies. He rates his problem of class fellows make fun of him 10 out of 10 which shows the severity of the problem and his awareness regarding his problem as well. Overall it was seen that client's most problem were interlinked and client had the awareness regarding his problem. And his least rating on 10 point scale was 8 which is an alarming indication of his severity of problems (Table 2). Subjective rating was taken from the teacher of the client in order to know about the severity level of the problem of the client. Teacher of the client rate his problem of weak in studies 9 out of 10 which shows the severity level of the client's problem as 9number is near to the total number of the rating scale. Teacher of the client rate problem of the client "problem in reading and writing" and "Didn't speak in class" both on 8 point out of 10 point. As 8 point is above average to the total number of the scale and near to the highest number it shows the severity level of the problem of the client. Overall it was assessed through subjective rating scale that client's most of the problems were near to the highest number of the subjective rating scale.

\section{Baseline chart'}

A baseline chart was developed for the bullying and fearfulness of the client (Table 3).

\section{Emotional behavioral assessment}

Emotional behavioral assessment was done with the help of school children problem scale. 
Table I Problems and their Severity Level Reported by the Client

\begin{tabular}{ll}
\hline Problem & Rating \\
\hline Being fearful while giving oral test in class or while reading in class & 10 \\
Difficulty in memorizing science lesson & 9 \\
Difficulty in reading and writing difficult words of Urdu and English & 10 \\
Some class fellows make fun of him & 10 \\
\hline
\end{tabular}

Table 2 Problems and their Severity Level Reported by the Teacher of the Client

\begin{tabular}{ll}
\hline Problem & Rating \\
\hline Weak in studies & 9 \\
Problem in reading and writing & 8 \\
Didn't speak in class & 8 \\
\hline
\end{tabular}

Table 3 Baseline Chart for Bullying and Fearfulness of the Client

\begin{tabular}{|c|c|c|c|c|}
\hline Activating Event & Belief & $\begin{array}{l}\text { Consequences } \\
\text { Feeling }\end{array}$ & $\begin{array}{l}\text { Consequences } \\
\text { Behavior }\end{array}$ & Result \\
\hline $\begin{array}{l}\text { In Ist period before arriving } \\
\text { of class teacher, one of class } \\
\text { fellow ask me to bring water } \\
\text { from the water cooler. }\end{array}$ & \multicolumn{2}{|c|}{$\begin{array}{l}\text { If I don't go now he will punish } \\
\text { me and bring his other fellows Anxious, fear full } \\
\text { too, to fight with me. }\end{array}$} & $\begin{array}{l}\text { I go to the water } \\
\text { cooler to bring water } \\
\text { for him. }\end{array}$ & $\begin{array}{l}\text { Before I came into class, class teacher } \\
\text { was arrived and he scold me for } \\
\text { wandering out of the class. }\end{array}$ \\
\hline $\begin{array}{l}\text { During break time, one of class } \\
\text { fellow came to me with his } \\
\text { bunch of fellows and ask me } \\
\text { to give his money and lunch } \\
\text { to him. }\end{array}$ & $\begin{array}{l}\text { They are so many if I don't } \\
\text { give them my money and } \\
\text { lunch they will beat me. } \\
\text { Whatever I don't give them } \\
\text { my money and lunch. }\end{array}$ & $\begin{array}{l}\text { Fearful, anxious and } \\
\text { nervous }\end{array}$ & $\begin{array}{l}\text { Didn't gave them } \\
\text { money and lunch. }\end{array}$ & $\begin{array}{l}\text { One of the class fellow slap on my } \\
\text { face and started calling my different } \\
\text { names and makes fun of me in front } \\
\text { of others, I go out of the canteen } \\
\text { area and starting crying. }\end{array}$ \\
\hline
\end{tabular}

School children problem scale: School children problem rating scale, was administered to assess the problem of the child in the anxiety, academic, aggression, withdrawal, rejection and somatic complaints effecting the academic performance of the child (Table 4).

Table 4 Child's score on the factors of the School Children Problem Scale

\begin{tabular}{lll}
\hline Factors & Obtained Scores & Severity Level \\
\hline FIAnxiety & 23 & Very Severe \\
\hline F2Academic & 15 & Very Severe \\
\hline F3Aggression & 15 & Very severe \\
\hline F4Withdrawal & 13 & Very Severe \\
\hline F5Rejection & 9 & Very severe \\
\hline F6 Somatic complaints & 6 & Very severe \\
\hline Total & 81 & Very Severe \\
\hline
\end{tabular}

Qualitative interpretation: The overall scoring of the child was on very severe which means that he was facing severe school problems, which were affecting his performance in the school and was also causing behavioral problems in him like aggression problem.

In the first factor indicator of the anxiety, child rate himself on very severe in this factor which means that his anxiety level was uncontrollable. Sometimes he become afraid of everything, he thought about random things, he didn't have the ability to convince next person. He was afraid of taking in front of someone; he didn't take initiative in activities or communicating with others.

On the indicator of the academic skills child scored on very severe, this factor showed his problems regarding the academic problems. Most of the time child didn't participate in the class, he was not able to concentrate on small tasks, he was also not bale to learn his lesson, and he was not able to do his work with responsibility. He was facing difficulty while studying because he didn't have any interest in the studies, he take school work as burden.

On the third factor which was indicator of aggression, the child scored on severe level on this factor which means that his level of aggression was very high. Child had inward anger. He was very naughty but he never abused anyone, he didn't speaks loud in class and sometimes talk during the class, he never lesson others, and he never make noise in the class. He shows his anger by breaking things but didn't reacting physically. On the withdrawal factor, the child's score on this factor shows that he withdraws from a situation. He remains silent, he got irritated easily. He was notable to make his anger out. Sometimes he didn't wants to meet his friends and he got angry on small things. Sometimes he wants to remain silent for no particular reason.

On the factor of rejection, child's score on this factor was very severe which means rejection level was high. He thought that no one loves him, or his parents love other siblings more than him, he had inferiority complex, he feel that no one loves him and everyone hates him. Sometimes he thought that his parents didn't give attention to him or they love more to his other siblings.

In the last factor for the somatic complaints, the child's score on this factor was very high. This showed his somatic complaints like palpitations, stomach pain, feeling tension in body when he's fearful or anxious.

The overall scores showed his school problems were very severe which was affecting his performance and attention toward his academic performance.

\section{Academic assessment}

Academic assessment was done with the help of copying, dictation and reading in order to know about his spatial skills, phonemic awareness, fluency and ability to comprehend the information.

Copying: Copying assessment was done in order to assess how attentively child can able to write a paragraph by copying a passage.

Child was given two types of paragraphs to copy from his course related books one paragraph is from English book and other paragraph 
is from science book. In copying different sub assessment was done like how much attention child gives to paragraph in order to write the passage his coding and decoding ability, Pencil grip and control of writing motion, legibility of handwriting and spacing of written words was assessed through copying a paragraph.

Overall it was seen that child had concentration problem because at the beginning of the passage he write carefully and then at the end of the passage he started doing mistakes like writing half word or totally different word. He writes the words with proper space but write some words incorrect. He face great difficulty while writing Urdu words which were composed of 3 to 4 alphabets.

Reading: Reading assessment was done to assess his reading and language comprehension and to know about his general reading ability.

Child was given two paragraphs from his text books one passage from English book and other passage from his Urdu book in order to assess his reading ability. Different abilities of the child regarding reading were assessed like identification of letters, symbols and accurate pairing of sounds with each symbol. Phonemic awareness and rapid autonomic naming. His fluency and accuracy in reading and comprehension of reading passages aloud.

It was assessed that child had difficulty in reading difficult words, he had problem in pronunciation of words and he was retrieving information from his previous knowledge like instead of reading word "Then" after seeing alphabet "T" he reproduced it as word "The". He didn't have phonetic awareness. He faces great difficulty while reading words which are consist of 3 to 4 latter.

Dictation: Dictation is the transcription of spoken text in which one person who is "dictating" speaks and another who is "taking dictation" writes down the words as they are spoken. Dictation was done in order to assess the child's ability to write, comprehend and decoding of the information.

Child was ask to bring his text books of English and Urdu and then child was informed about the directions of performing dictation. During the assessment child ask one sentence or word more than one time which shows he's not listen attentively or he had difficulty in comprehend the information which was providing to him or he had difficulty in understanding the word. It shows child had difficulty in writing a sentence without a prompt. He didn't write words properly like when he was asked to write "then" he write the and in Urdu he also writes words incorrectly which shows he had difficulty in writing English and Urdu words.

Overall from academic assessment it was assessed that child had difficulty in reading and writing difficult words it was might be because he had little knowledge or he's not familiar with the words. He had difficulty in decoding of the information it was might be he picked up several things at once like look around and divert his attention which create difficulty in maintaining attention and automatically it makes hindrance in his academic performance.

Academic assessment rules out writing problem and difficulty in pronunciation and reading of difficult words. Child didn't have phonetic awareness which creates hindrance in reading and writing English and Urdu words.

\section{Cognitive assessment}

Cognitive assessment was done to determine individual's cognitive abilities and to recognize the presence of impairment in his cognitive functioning. For the purpose of cognitive assessment paired associate learning test and reading test was administered on the client.

Paired associate learning test ${ }^{2}$ : Paired associate learning test was administered on the child to know either he had ability to learn over the periods of trial, and for assessing explicit episodic memory of the client. Before administrating the pair associate learning test, ask the client to listen carefully each pair of words e.g. table- chair in order to retrieve theses pair of words when asking one of pair during test. According to standard procedure, the verbal directions were given (Table 5)

Table 5 Childs Performance on the Paired Associate Learning Test

\begin{tabular}{llllll}
\hline Trial I & & Trial 2 & & Trial 3 & \\
\hline Easy & Difficult & Easy & Difficult & Easy & Difficult \\
6-Apr & 4-Feb & 6-Jun & 4-Mar & 6-Jun & 4-Apr \\
\hline
\end{tabular}

Qualitative interpretation: Overall on easy words child took minimum 2 seconds for retrieving the pair of word on the other in difficult task client took overall maximum 3 to 4 seconds to retrieve the information.

On trial 1 in easy words child scored $4 / 6$ which indicate that client have problem in understanding of semantics which means in understanding of words, their relationship like in first trial of easy words like data/ looha client was unable to understand the relationship between these words that's why unable to retrieve in test. On difficult world client score $2 / 4$ which means on illogical words, he was unable to retrieve pair of words such as Goobi/ qalam, hukam/gazz, kitaab/ and heer a which indicate that child had difficulty in memorizing words which had dissimilar relationship.

On trial 2 of paired association learning test client scored $6 / 6$ in easy words it could be estimated that initially child had difficulty in listening comprehension which means he had difficulty in listening and then comprehends the information but with rehearsal he can memorize easy words without difficulty. Client scored 3/4 in difficult words in trial 2 which indicate that after first trial child was still not able to correct his mistakes in next trial his speed of processing and memorizing is slow or might be had attentional problem.

In trial 3 client scored $6 / 6$ in easy words and he scored 4/4 in difficult words. Which indicate that client had ability to recall paired words after number of trials.

Client's overall performance on paired association test was satisfactory as at the last trial he was able to scored $4 / 4$ in difficult words which in $1^{\text {st }}$ trial he scored $2 / 4$. It means firstly client face difficulty in illogical word association but he was able to learn with number of trials and practice. And clients explicit memory can be enhanced with rehearsal and training over trials.

\section{Urdu reading}

(Wechsler, 1945) To check word recognition, subject familiarity, verbal fluency, comprehension, reading quality, level of text of the child because it was reported by the teacher that child had poor grades in Urdu reading subject. Before administration verbal instructions regarding test was given to the client. Test was administered in the session room. Although client was distracted few times because of the sound coming from surrounding (Table 6).

Qualitative interpretation: The client was 12years old and studied in class $7^{\text {th }}$. His overall performance on Urdu reading test was satisfactory 
but he had done some mistakes which were not be considered from $9^{\text {th }}$ grade student.

Table 6 Performance of the Child on Urdu Reading Test

\begin{tabular}{ll}
\hline Total Score & Class Equivalence \\
\hline 55 & Class 4 \\
\hline
\end{tabular}

Client was doing very inconsiderate mistakes that was might be because of the problem in explicit memory of the child because client was unable to retrieve information on which he put on a lot of conscious effort to memorize.

Client was with the comprehension difficulty because of Poor reading comprehension and word recognition. Child was also with poor listening comprehension as he was distorted a word while pronunciation. So it might be the reason of poor pronunciation that child listen the word incorrectly and then encode as it in memory and retrieve it as in future.

Client faced difficulty in encoding in which client was unable to receive, process and combine the received information that might be because of the comprehension problem. In storage of information client face difficulty in permanent record of the encoded information that might be because of less number of trials of recalling and reading of words. Client had difficulty to calling back the stored information in response to some cue as it was also shown from his performance on the test.

Client's verbal fluency was also poor as he took much time on pronunciation of one word. E.g. word "Aqa" and he pronounce it as "Aaq". It means he is unable to pronounce a word fluently. Clients level of text and subject familiarity was also poor as he was unable to read the words which was taken from his current class slybus. Client also had problem in word recognition as he pronounces word "Phooldar" as Phaldar" Other reason of the problem of the client might be lack of attention by the teacher and by himself as he didn't try hard to study.

Digit span²: Digit span test was used to assess the memory of the child through giving two trials, one is forward and second is backward (Table 7).

Table 7 Backward and Forward Scores of the child on Digit Span

\begin{tabular}{lll}
\hline Backward Score & Forward Score & Total Score \\
\hline 5 & 6 & II \\
\hline
\end{tabular}

The child was able to memorize 6 sets of the digits in forward and after that he was not able to memorize further series of sets of digits. In backward pattern child was able to memorize till 5 series of digits. After that child was not able to memorize the whole series of the numbers, the child started missing and misplacing the numbers. As he was 14years old according to her mental and functional age his scoring on the digit span was satisfactory.

Logical memory ${ }^{2}$ : In order to measure the immediate recall of verbal ideas logical memory test was administered on the client.

Before administration of the logical memory test verbal instructions regarding test were given to the client (Table 8).

Table 8 Performance of the Child on Logical Memory

\begin{tabular}{ll}
\hline Total Score & Achieved Score \\
\hline 25 & 9 \\
\hline
\end{tabular}

Qualitative interpretation: Clint was having difficulty in memorizing difficult words in the test like "Kotlakhpath" it confirms the client's problem that client had difficulty in memorizing and retrieving difficult words in English and Urdu language as well. Client didn't memorize some easy words like "kal sham" "Mulazma" which shows that while memorizing his lesson client didn't make any links or connections to use information for long term purposes he just read the line because of which he didn't able to save the information in the long term memory and because of just reading without making any links he didn't able to store the information even into the short term memory.

Overall performance of the client on logical memory was satisfactory as he was able to tell the crux of the story but he was not able to tell the details of the story like he skipped important information like children of the maid, from two days they are hungry and maid had to pay rent of the house. Client also didn't tell the name of the street where the maid was robbed.

\section{Reinforce identification}

Multiple rein-forcers were identifying for the client in order to keep him busy in activities and in order to maintain the rapport with the client. Client loves to talk about his future, he also loves to talk about cricket.

Following are the primary rein forcers of the client.

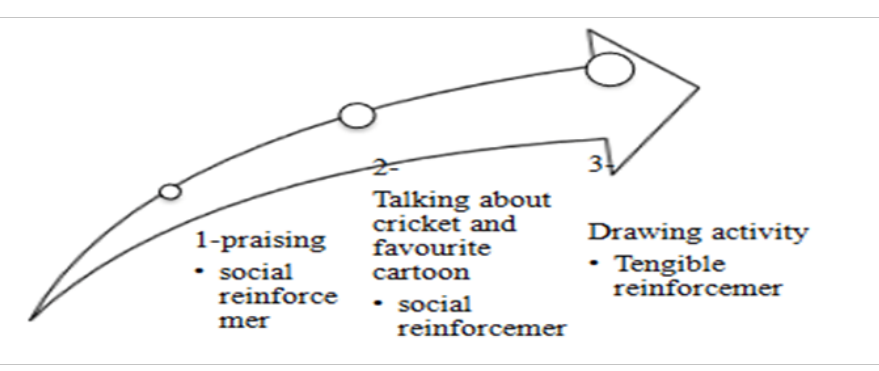

\section{Case formulation}

The child M.A was 12 year old boy, the child was referred with the complaints of weak in studies, problem in reading /writing and didn't speak in class. During the session in clinical interview client report certain presenting complaints like being fearful while giving oral test in class or while reading in class, difficulty in memorizing science lesson, difficulty in reading and writing difficult words of Urdu and English, some class fellows make fun of him. Assessment results exposed the different psycho-social features which contribute the child's problem. According to Barry ${ }^{3}$ lower socioeconomic status students often display difficulty with language skills and struggle with reading. Lower socio economic status ultimately contributes to lower academic performance and slower rates of academic progress. As with the case of client it was also seen that poor performance in the school might be because of client belongs to a poor socio economic status background.

As client had a problem in school, his class fellows make fun of him according to Cheever ${ }^{4}$ people who are being bullied by their school mates had more academic, emotional, social and physical problems than others. As in the case of the client we can see that he didn't take notice or any action towards those class fellows and silently being bullied from them. He had academic problem as he couldn't read and write well difficult words and some simple words as well. He had emotional problem as well as he gets nervous and fearful at the time of reading in class. He had physical symptoms as well like palpitations, stomach pain, feeling tension in body and sweating etc. Client had social problem as well as he didn't make friends in school he had only one best friend. 
As client reported he thought his mother is more affectionate towards his younger brother according to McHale et al., ${ }^{5}$ in their study found that if parent's had differential treatment with younger once then the elder once feel jealousy and it's the strongest factor of siblings rivalry it can also affect the mother child or father child relationship bonding as well. As in the case of child it was seen that mother of the child beat the client when he fought with his younger brother by saying your younger brother is innocent because he's youngest of you, you should be careful while playing. This makes the client to had distant relationship with his younger brother. As client was with the problem of low academic achievement according to Gewen ${ }^{6}$ found that children from authoritarian families tend to be less resourceful, have poorer social skills, and lower self-esteem. compared with kids from authoritative households, kids exposed to authoritarian discipline may also achieve less at school in the case of client it was also seen that authoritarian parenting style of client's parent might be one of the factor of his lower academic performance at school. Overall it was seen that in the case of the client lower socio economic status is one of the predisposing factors of the client's problem. Parental demanding attitude regarding getting good grades and school bullying one of the precipitating factors of the client's problem. Conflicted home environments, father's peevish attitude, client's perceived affectionate relationship towards his younger brother were maintaining factors of the client's problem. Client's own concerns to sort out his problem in studies, loving and caring relationship with elder sister were one of the protective factors of the client. Conflicted home environment, father's peevish attitude, client's perceived affectionate relationship of his mother towards his younger brother, bullying at school, bringing stuff from bazaar for his neighbors and home were the risk factors of his problem.

\section{Summary of the case formulation}

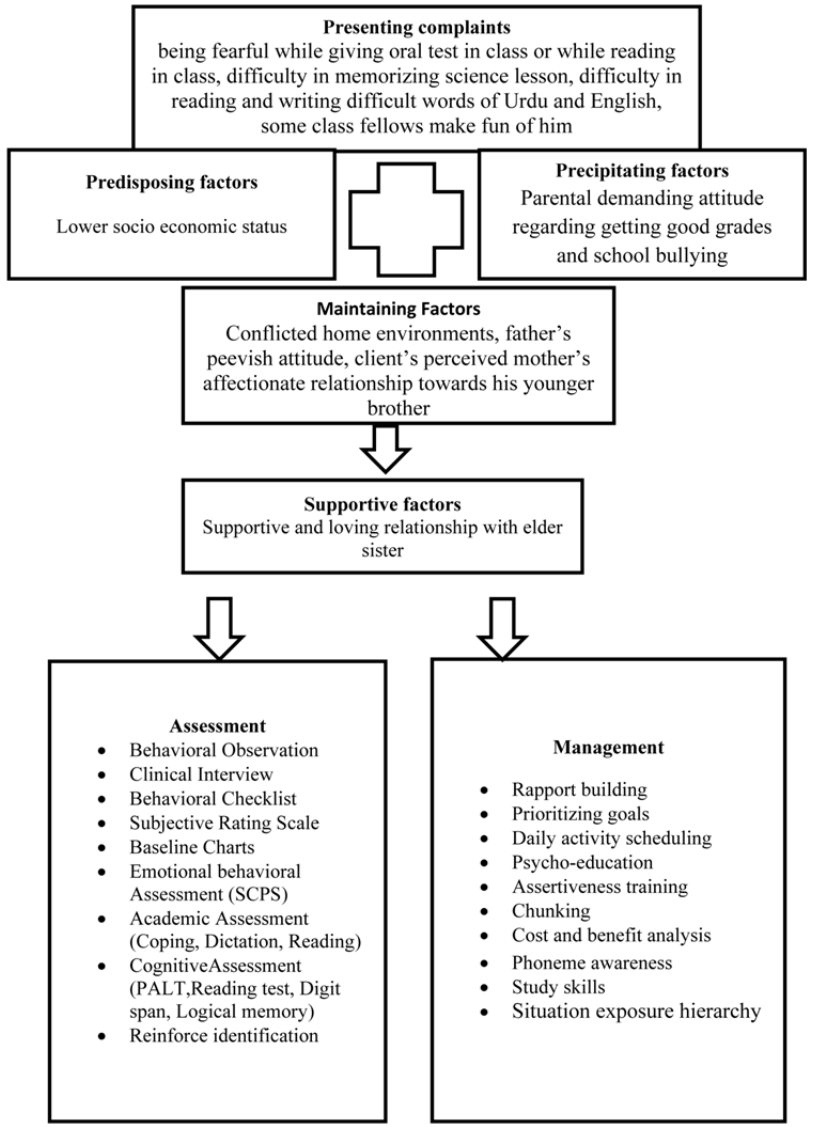

\section{Intervention plan}

Following intervention plan used with the client in order to achieve his goals and to overcome his problems (Table 9).

\section{Counseling strategies}

Following are the counseling strategies were used with the client in order to achieve the goals to manage his problems.

Rapport Building: To have a fine therapeutic relationship rapport building is used. In order to enhance the therapeutic relationship with the client rapport building was done with the client. Initially client was defensive and he was not ready to share any problem or disclose any personal information with the therapist. Rapport was built with the client by asking about his best experiences in life, his most favorite game, activities and food. By doing drawing activities during initial sessions, talking about cricket and his favorite cartoon character, with the help of rapport building client was able to report about his problems.

Prioritizing goals: It is a procedure in which a person decides what he wants out of the therapy. Then small goals are decided to fulfill the final goals.

The rationale of this technique is to decide about the target goal so that the client and the psychologist should be clear about their final destination.

M.T decided about the goals with the psychologist. For him most important goal was to overcome his bullying problem, fearfulness while reading in class, overcome his academic problem like memorizing reading and writing English and Urdu words and as well science lesson. ${ }^{?}$

Psycho-education ${ }^{8}$ : Psycho-education was use to teach, regarding current situation and how to cope up with different difficulties in life.

Client was psycho-educate regarding importance of studies and client was psycho-educate regarding the importance of life and different aims of his life. As client wants to join army he was psychoeducate that if he didn't study hard he will not achieve his goal. In order to join army and to get a bicycle from his parent's he needed to get good grades.

Client was psycho-educate regarding changing his perspective regarding his mother that she loves more his younger brother. He was psycho-educate that his mother scold him because he's elder than his younger brother she wants client to be mature and to be a helping sibling like his elder sister.

He was psycho-educate regarding being victim in school. He was psycho-educate that if he didn't tell any elder person about it he will continue to face the consequences.

Daily activity scheduling8: In order to keep the person busy in a schedule, daily activity schedule was used.

In order to handle the client's problem like difficulty in memorizing science lesson and reading and writing difficult Urdu and English words. And his problem of less talkative in school daily activity scheduling was used with the client. Daily activity scheduling was done with the client which helps the client to engage in certain activities with time, which helps the client to study at home starting from half an hour for the first week of activity scheduling. And to participate in class and communicate with other in class and performing daily prayers. 
Table 9 Intervention Plan of the Client

\begin{tabular}{|c|c|}
\hline Goals & Intervention Plan \\
\hline In order to strengthen the therapeutic relationship & $\begin{array}{l}\text { Rapport building } \\
\text { Prioritizing goals }\end{array}$ \\
\hline To overcome bullying problem of the client & $\begin{array}{l}\text { Changing old rules/ assumptions into new rules/ } \\
\text { assumptions }\end{array}$ \\
\hline To overcome problem of letting stuff from bazaar when he's studying and victimizati & ${ }^{\mathrm{n}}$ Cost and benefit analysis \\
\hline \multirow{2}{*}{$\begin{array}{l}\text { To overcome his perceived affectionate behavior of his mother towards his younger } \\
\text { brother }\end{array}$} & Assertiveness training.(broken record technique) \\
\hline & Psycho-education \\
\hline $\begin{array}{l}\text { To overcome phoneme awareness problem and reading/ writing English and Urdu } \\
\text { difficult words }\end{array}$ & $\begin{array}{l}\text { Phoneme awareness (word families chart) } \\
\text { Chunking }\end{array}$ \\
\hline $\begin{array}{l}\text { To overcome the problem of memorizing science lesson. And being less talkative in } \\
\text { class }\end{array}$ & $\begin{array}{l}\text { Study skills } \\
\text { Chunking } \\
\text { Psycho-education }\end{array}$ \\
\hline Fearful while reading in class & $\begin{array}{l}\text { Daily activity scheduling } \\
\text { Situation exposure hierarchy }\end{array}$ \\
\hline
\end{tabular}

These activities were done with the help of the client. And these were the priorities of client in daily activities. Because of daily activity scheduling client's problem will be lessen.

\section{Bullying management}

Cost and benefit analysis ${ }^{8}$ : It is a method of finding the advantages and disadvantages of a thinking style. When a person comes to know about the advantages and disadvantages of his thought pattern he can change his style and lead a better life.

Client was asked to write advantages of not telling about his bullying in school to any elder person like parent's elder sibling or any school teacher. And after that he was asked to write down disadvantages of not to tell any authority person regarding his bullying at school.

Then he was asked to weigh them and tell which is better. Because of this activity client was able to identify which is more better for him. And at the end of the session after the activity client was thankful to the therapist and said he never thought about the benefits of telling about his victimization.

Changing old rules/assumptions into new rules/ assumptions: (Leahy, 2003) In order to change the thinking pattern and to make the person able to come up with alternative believe.

We are often abandoning on one belief unless we can come up with an alternative that can work better for us. Client M.T will ask to make should statements for him in order to motivate himself to tell about his victimization to and authority figure like parent's, teacher and elder siblings. Previously he hold a believe that he didn't tell about his bullying at school to he should tell about his victimization o authority figure in order to stop the bullies to make him victim.

Assertiveness straining: Is the quality of being self-assured and confident without being aggressive.

Broken record technique': The broken record technique employs the key assertive skill of 'calm persistence. It involves repeating what you want, time and time again, without raising the tone of your voice, becoming angry, irritated, or involved in side issues. It consists of simply repeating your requests or your refusals every time you are met with resistance.

As client had problem that his class fellows ask him to bring something at the time when class teacher was about to come in class.
The client was trained to tell them he will bring the stuff out of the class when he asked from the class teacher. he will do this , because of it client will be save from the teacher's punishment.

As client had also problem that his neighbors or from family member they asked him to bring something from bazaar at the time of study when he had any important test in tuition or school. He will refuse them by saying I will do this after finishing my work till then you people have to wait for me.

Because of this technique client understand how to say "NO" without any problem or issue.

Study skills ${ }^{10}$ : Study skills are strategies and methods that aid learning. As client had study related problems like difficulty in memorizing lesson, concentration problem and didn't want to study at home.

Time table was given to the client to follow the instructions and then continue his studies over the whole day so that he becomes able to sharpen his study skills. Because of the time table he was able to give minimum half an hour to his studies (see appendix E4f).

Chunking ${ }^{11}$ : Chunking technique was used with the client to teach him how to remember long English words. Firstly chunks were made and then ask the client to remember according to the chunks (See Appendix B2e).

Outline of chapter and long questions: Chunking procedure was used to teach the client how to make a whole long answer or a chapter's outline to remember the question more easily. In order to memorize the long answers of the science subject he was asked to firstly make an outline and then fill in the information according to the outline.

The activity was very fruitful as client was able to make the long answer into chunks and in an outline and then the process of memorizing was become easier for him.

PQRST method: One method used to focus on key information when studying from books is the PQRST method. This method prioritizes the information in a way that relates directly to how they will be asked to use that information in an exam. PQRST is an acronym for Preview, Question, Read, Summary and Test.

Preview: The student looks at the topic to be learned by glancing over the major headings or the points in the syllabus.

Question: The student formulates questions to be answered following a thorough examination of the topic. 
Read: The student reads through the related material, focusing on the information that best relates to the questions formulated earlier.

Summary: The student summarizes the topic, bringing his or her own understanding into the process. This may include written notes, spider diagrams, flow diagrams, labeled diagrams, mnemonics, or even voice recordings.

Test: The student answers the questions drafted earlier, avoiding adding any questions that might distract or change the subject.

As client had rote learning style of learning it implies a passive reading or listening style. PQRST method helped him to overcome his rote learning style of learning with critical thinking (See Appendix B2f).

Phoneme awareness: is the ability to hear and manipulate individual phonemes. Phonological awareness includes this ability, but it also includes the ability to hear and manipulate larger units of sound, such as onsets and rhymes and syllables.

In order to give the phonetic awareness to the client different phoneme awareness activities was used with the client like word family chart and word phonics flip book.

Word family chart $^{12}$ : are groups of words that have a common feature or pattern they have some of the same combinations of letters in them and a similar sound. For example, at, cat, hat, and fat are a family of words with the "at" sound and letter combination in common.

Client was given different combination of alphabets and he was asked to join the alphabets and make different words out of it. It will further help him out in memorizing difficult English words.

Word phonics flip book ${ }^{13}$ : It focuses on blending and chunking of words. In order to make the phonic flip book therapist cut cards so that roughly $2 / 3$ rds of the card was on the right and $1 / 3$ on the left. Then therapist will used this list of most common word families as discovered through the book, Kid Writing, and added them in the top cover. Then therapist will added the first letters and beginning blends. Some of the blends will added to our chart will included: ab, ad, bl, cl, fl, gl, pl, sl, br, cr, dr, fr, gr, tr, th, sh, ch, wh, sch, sk, sn,sm, sp, st, str, sw, kn, etc. The majority of the words in the English language can be created from the blending of these "word families" and the various "beginning" combinations.

Then client will be asked to blend different alphabets and make different words out of them.(See Appendix B2h).

Situation exposure hierarchy ${ }^{7}$ : Situation exposure hierarchy technique of CBT was use with the client in order to motivate him to reading in class first it will ask from the client to make a top and lowest hierarchy of reading lesson during class e.g. firstly stat with simple Urdu passage and then gradually increase the length of the paragraph and difficulty level of the paragraph.

\section{Proposed management}

Below are the counseling techniques which will be use with the client in future counseling sessions. Further step for phoneme awareness techniques should be continued.

\section{Termination}

Client was terminated after 12 numbers of sessions. It was very challenging case because client was very challenging. There was predominant and noticeable change in client's way at looking things. His academic problems were lessened. He was satisfied with the therapeutic relationship and its outcomes. At the end post subjective rating were taken from the client. ${ }^{14,15}$

\section{Outcome}

He was referred by the teacher for the management of his academic problems. Complaints which were reported by his teacher were Weak in studies, problem in reading and writing and didn't speak in class. During the session in clinical interview client report certain presenting complaints like being fearful while giving oral test in class or while reading in class, difficulty in memorizing science lesson, difficulty in reading and writing difficult words of Urdu and English, some class fellows make fun of him. After termination post ratings were taken in order to access the improvement in the client. Pre and post-ratings are mentioned below in the table and a graphical form also mention below to see the change in pre and post subjective ratings and assessment of problems of the client (Table 10-12) (Figure $1 \& 2$ ).

Table 10 Pre and Post Rating of Problems and their Severity Level Reported by the Client

\begin{tabular}{lll}
\hline Problem & $\begin{array}{l}\text { Pre } \\
\text { Rating }\end{array}$ & $\begin{array}{l}\text { Post } \\
\text { Rating }\end{array}$ \\
\hline $\begin{array}{l}\text { Being fearful while giving oral test in class } \\
\text { or while reading in class }\end{array}$ & 10 & 7 \\
$\begin{array}{l}\text { Difficulty in memorizing science lesson } \\
\text { Difficulty in reading and writing difficult }\end{array}$ & 9 & 6 \\
$\begin{array}{l}\text { words of Urdu and English } \\
\text { Some class fellows make fun of him }\end{array}$ & 10 & 6 \\
\hline
\end{tabular}

Table II Problems and their Severity Level Reported by the Teacher of the Client

\begin{tabular}{lll} 
Problem & Pre Rating & Post Rating \\
\hline Weak in studies & 9 & 7 \\
Problem in reading and writing & 8 & 7 \\
Didn't speak in class & 8 & 5 \\
\hline
\end{tabular}

Table 12 Child's Score on the factors of the School Children Problem Rating Scale

\begin{tabular}{lllll}
\hline Factors & $\begin{array}{l}\text { Pre } \\
\text { Scores }\end{array}$ & $\begin{array}{l}\text { Severity } \\
\text { Level }\end{array}$ & $\begin{array}{l}\text { Post } \\
\text { Scores }\end{array}$ & $\begin{array}{l}\text { Severity } \\
\text { Level }\end{array}$ \\
\hline FIAnxiety & 23 & Very Severe & 17 & Moderate \\
\hline F2Academic & 15 & Very Severe & 12 & Very severe \\
\hline F3Aggression & 15 & Very severe & 9 & Severe \\
\hline F4Withdrawal & 13 & Very Severe & 10 & Severe \\
\hline F5Rejection & 9 & Very severe & 6 & Very severe \\
\hline $\begin{array}{l}\text { F6 Somatic } \\
\text { complaints }\end{array}$ & 6 & Very severe & 4 & Moderate \\
\hline Total & 81 & Very Severe & 58 & Severe \\
\hline
\end{tabular}

Pre and Post subjective rating of the problems of the client reported by the client

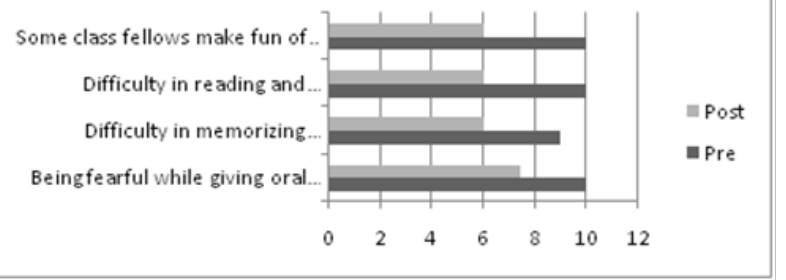

Figure I Bar chart representing pre and post rating of problems and their Severity level reported by the client. 


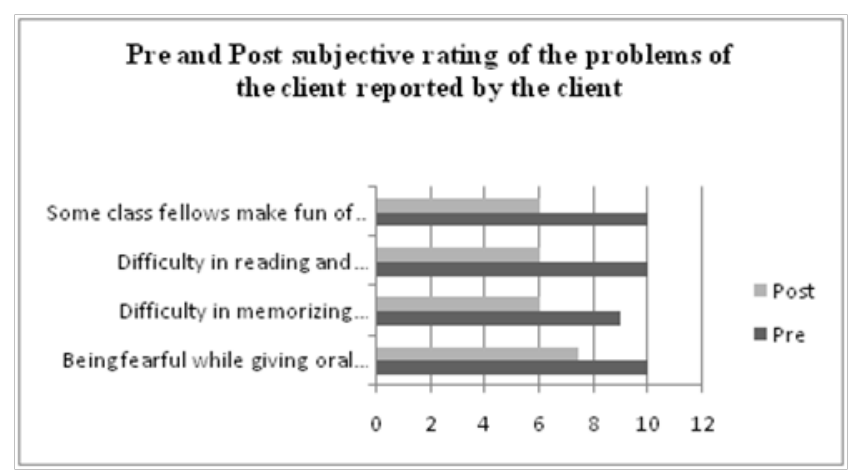

Figure 2 Bar chart representing pre and post rating of problems and their Severity level reported by the teacher of the client.

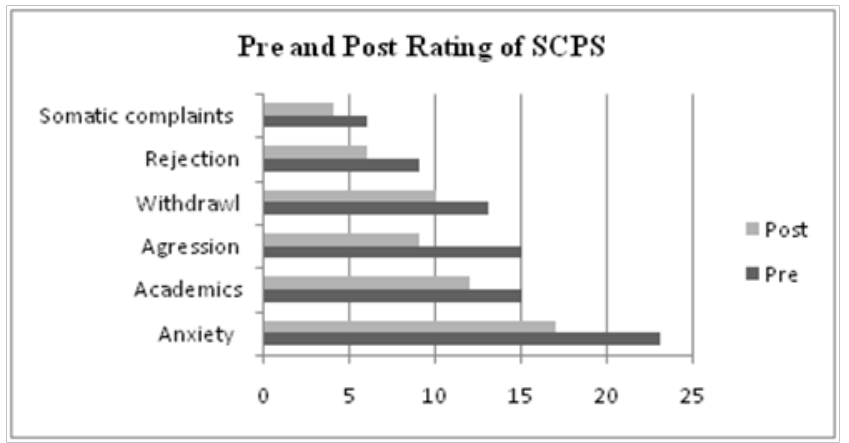

Figure 3 Bar chart representing pre and post rating of school children problem scale.

Qualitative interpretation: There is noticeable change in client's pre and post rating of School children Problem Scale. As before the therapeutic intervention client rate on anxiety factor 23 but after the therapeutic intervention client's scoring on anxiety was 17 although nor any work on anxiety was done but it might be lessened because of any other factor like rejection or as he didn't speak in class and as he was bullied in the school when intervention was done on his bullying issue it automatically lower down his anxiousness as well. Client's aggressive behavior was not observed during the behavioral observation or neither he reported it in clinical interview. So it was suspected that client had inward aggression. And client's rating on aggression was also lessen it was might be because of the management on bullying problem of the client. Client's scoring on academics was also lessen but it was a big change for client as he rarely read in class but now he started reading in the class. It was a noticeable change as after management client starting doing study at home. Over all in pre and post scoring noticeable change was seen in client's scoring on most of the factors of School Children Problem scale (Figure 3).

\section{Limitations}

There are number of limitations which caused hindrance in management of the client's problem.

a. Unavailability of the teacher for the clinical interview was one of the limitation which can create hindrance in the process of identifying cause of the problem of client's poor academic problem.

b. Unavailability of the parents was also a limitation.

\section{Recommendations}

It is recommended to Psycho-educate the parents regarding the clients studies that parent's don't punish him when he get passing marks in exams.

\section{Session Reports}

\section{Session \# 1: Date: 7-4-2015}

In the first session with the client different activities were used in order to build the rapport with the client such as asking about his favorite activities, games, food and client was observed in the session. Role of the counselor was defined to the child in order to make the report. And client was observed during the whole session. Drawing activity was done with the client for the purpose of rapport building.

\section{Session \# 2: Date: 8-4-2015}

In the second session history taking and clinical interview was done in order to know about the detail of the client's present problem client was also observed during the whole session. Referral form was taken from the teacher of the client and family history was taken from the client. Rein forcers of the client was asked. Drawing activity was done. Rapport was built and client discussed about his familial relationships.

Client was asking about his future plans and he was also ask about his daily routine client was brief about what is meant to be reinforce. Client was open up with the therapist and discuss his daily routine and what he wants to be client understand the concept of reinforce as well.

\section{Session \# 3: Date: 12-4-2014}

In the third session behavioral observation and clinical interview was done with the client. SCPS was administered on the client. Client was asked about his future goals and he was also asking about study related problems. Outcome of the session was fruit full as he discuss his future goals and also discuss what type of problems he face in studies.

\section{Session \# 4: Date: 11-11-2014}

In the fourth session coping activity was done with the client in whom he was asked to write a paragraph of Urdu and English passage by coping. Through this his writing ability was assessed. Drawing activity was done with the child. Because of the session activities It was assessed that child had difficulty in coping paragraph as he done number of mistakes like omission etc.

\section{Session \# 5: Date: 15-4-2015}

Behavioral observation and clinical interview was done with the child and reading test was administered on the child. The child was asked about read a paragraph from his text book. Child was asked about daily routine. The outcome of the session was fruitful as his reading ability was assessed and Child's daily routine schedule was discussed.

\section{Session \# 6: Date: 16-4-2015}

In the $\mathbf{6}^{\text {th }}$ session behavioral observation, clinical interview was done and Pared associate learning test was administered on the client. Different activities were done with the client like diary writing and dictation activity was done with the child. Overall session activities were fruitful as his ability to retrieve information was assessed which later on help in management of his problem.

\section{Session \# 7: Date: 22-4-2015}

Behavioral observation and clinical interview was also done with the child. Different activities were done with the client during the session like Child was psycho-educate regarding the importance of 
education. Client was asked to write down good and bad qualities of school going children. Daily activity scheduling was done with the client in order to make his routine to study at home. Overall outcome of the session was fruitful as child understands the importance of daily activity scheduling.

\section{Session \# 8: Date: 23-4-2015}

In the eight sessions behavioral observation clinical interview and dictation was done with the child. Chunking was done with the child to remember long English words. Changing old rule belief into new assumption activity was done with the client. overall session outcome was fruit full as Child's ability to write words without coping was assessed which will help further in management of his academic problem. Child understands how to memorize spellings.

\section{Session \# 9: Date: 28-4-2015}

Client was asked about his favorite teacher. Urdu reading and Digit span test was done in the session. Client was again asked about his problem regarding studies. Chunking was done with the client. Overall outcome of the session was fruit full as Urdu reading ability of the client was assessed. Through Urdu reading and Digit span test his ability to read Urdu and his ability regarding how many numbers/ digits he can memorize was assessed which can further help out in the management of his problem. And client knows how to make chunks of paragraphs or words to make them memorize more easily.

\section{Session \# 10: Date: 29-4-2015}

Logical memory test was administered on the client. Client was informing regarding assertiveness techniques. Cost and benefit analysis regarding studies was done with the client. Overall outcome of the session was fruitful as Client's logical memory was assessed. Clients know regarding assertiveness and different strategies. Client's view regarding studies was assessed.

\section{Session \# 11: Date: 20-5-2015}

Clinical interview and behavioral observation was done with the client. Different activities were done in the session as Client was asking about previous group activities and feedback was taken from the client. Client was psycho-educate regarding how to get good marks in the exams, and importance of study at home. Overall outcome of the session activities was fruitful as feedback regarding previous group was taken and client knows about the importance of study at home, client also know how to get good marks in exams.

\section{Session \# 11: Date: 26-5-2015}

Behavioral observation and clinical interview was done with the client. Different activities were done in the session as feedback regarding bullying group was taken from the client. SCPS scale was administered on the client and post rating of the client's problem was taken from the client. Session outcome was fruitful as post rating of the client's problem was taken, and client's feedback regarding the bullying group was also taken.

\section{Acknowledgements}

None.

\section{Conflict of interest}

Author declares there are no conflicts of interest.

\section{Funding}

None.

\section{References}

1. Spiegler M, Guevremont D. Contemporary Behavior Therapy, $\left(5^{\text {th }}\right.$ edn $)$, Wadsworth, USA. 2003.

2. Wechsler D. Wechsler memory scale. The psychological Cooperation, New York, USA. 1945.

3. Barry J. The effect of socio economic status on academic achievement. Journal of Psychology. 2005;5(3):15-25.

4. Cheever J. Common causes of bullying in elementary schools. 2002.

5. McHale SM, Crouter AC, McGuire SA, et al. Congruence between mothers' and fathers' differential treatment of siblings: Links with Family Relations and Children's Well-Being. Child dev. 1995;66(1):116-128.

6. Gwen, Dewsar. Authoritarian parenting: How does it affect the kids. 2000-2013.

7. Leahy RL. Cognitive therapy techniques: Practitioner guide. The Guilford press, New York, USA. 2003.

8. Kayler, Sherman. Psychotherapy and re-education. The Journal of Abnormal Psychology. 2009;6:1-10.

9. Smith MJ. When I Say No, I Feel Guilty. 1975.

10. Donoghue R. Study skills: Managing your learning access office: NUI Galway, Ireland. 2005.

11. Miltenberger RG. Behavior modification: principles and procedures. Brooks/ Cole Publishing company, USA. 1997.

12. Richard Wylie E, Donald Durrell D. Teaching Vowels through Phonograms. Elementary English. 1970;47(6):787-791.

13. Rachel. Words families flip chart. 2013.

14. Braaten E. The Child Clinician's Report-writing Handbook. The Guilford press, New York, USA. 2007.

15. Krull E. Replacing Your Negative Thoughts. Psych Central. 2010. 